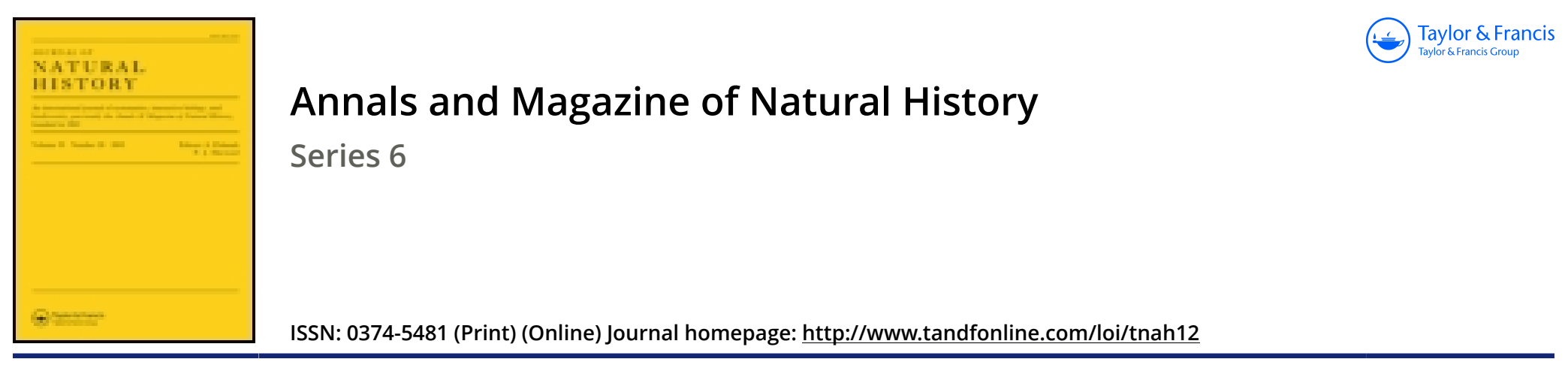

\title{
XXV.-On the presence of Wood-Mason's stridulating-organ in Trechona zebrata (Walck.)
}

\section{R.I. Pocock}

To cite this article: R.I. Pocock (1896) XXV.-On the presence of Wood-Mason's stridulatingorgan in Trechona zebrata (Walck.), Annals and Magazine of Natural History, 17:98, 177-179, DOI: $10.1080 / 00222939608680344$

To link to this article: http://dx.doi.org/10.1080/00222939608680344

Published online: 06 Oct 2009.

Submit your article to this journal $₫$

Џ Article views: 3

Q View related articles $\square$ 
XXV.-On the Presence of Wood-Mason's Stridulating-Organ in Trechona zebrata (Walck.). By R. I. Pocock.

Mr. Thomas Workman of Belfast has recently kindly drawn my attention to the paper entitled "Remarks on the Falces and Maxillæ of Spiders," published in the Annals \& Mag. Nat. Hist. (3) xix. pp. 258-259, pl. x. fig. 3 (1867), in which Mr. John Blackwall describes and figures part of the stridulating-organ of one of the Theraphosidæ, which he called Mygale zebra. On p. 259, after discussing the inappropriateness of the term teeth as applied to the abbreviated spines which stud the base of the maxilla and the apex of the labium in the spiders of the family "Mygalidæ," he observes: " but to a remarkable group of spines, situated on the superior surface of the maxilla of Mygale zebra, and clearly indicating, by its position and structure, that the principal function it performs must be that of mastication, the appellation of teeth appears to be more appropriate. 'The spines composing this group, which are of a dark-brown colour, and have their pointed extremity directed towards the inner margin of the maxillæ, are fewer in number, enlarged at the extremity, and much longer and more distinct near the posterior end of each group than the closely compacted ones that form its anterior part. These spines, by their figure and arrangement, present a highly interesting subject for inspection under the microscope." This description and the figure that accompanies it leave no room for doubt that the author had before him the cluster of modified hairs constituting the notes or keys of the stridulating-organ that was subsequently described by Wood-Mason. That he failed to discover the true significance of the organ is perhaps not surprising, seeing that he had never been previously informed, as had WoodMason, that these spiders are able to emit sounds.

The chief interest, however, of the discovery lies in the fact that Mygale ztbra, or rather Trechona zebrata, as it should be called, is a South-American species; and no other member of the family from this country, which is perhaps, so far as the Theraphosida are concerned, the richest in the world, is known to possess this stridulating-organ. In fact, in connection with this subject, I remarked, on p. 168 of the 'Annals' for February last, "no organ resembling either of those [the two types of stridulators occurring in the oriental genera*] mentioned above is found in any genus that $[$ have

* See also 'Natural Science,' vi. pp. 41-50.

Ann.\& Mag. N. Hist. Ser.6. Vol. xvii. 
examined of the following Neotropical groups:-Aviculariex, Eurypelmatex, Theraphosea, and Homcommateæ."

The genus Trechona, however, belonging to a distinct subfamily-namely, that of the Diplurinæ,-and represented in the National Collection by a single dried example, which will very possibly prove to be Walckenaer's type, I did not examine for this organ, for fear of causing needless damage to a valuable and unique specimen. But upon reading Mr. Blackwall's article, 1 immediately took the necessary steps to verify his statement, and was rewarded by finding the organ almost exactly as he described it. The set of notes on the maxilla is of large size, and occupies nearly the whole length of the inner surface of this segment. The notes coraposing the distal two-thirds of the group are black and thickly clustered together; they are not, however, short and spicular as Black wall's figure represents, but long and straight. Those, on the contrary, that compose the proximal third of the cluster are thicker, more separated from each other, curved, and arranged in a single line, the individual notes gradually decreasing in length as they pass from the centre of the cluster to its proximal end. The modified hairs on the opposable surface of the mandible, which Blackwall does not mention, are constructed on very much the same plan as the corresponding hairs that $\mathrm{I}$ have described in Psalmopeeus Cambridgii * - that is to say, they consist of a small number of long, thick, but apically filiform setæ set on the posterior portion of the lower edge of the jaw, and these pass into a set of rigid setæ, which ultimately blend with the hairs at the base of the fang.

A point to be noticed in connection with the occurrence of this remarkable organ in a Neotropical genus belonging to a subfamily with which the Oriental stridulating Selenocosmiidæ seem to have no special affinity, is the unavoidable conclusion that substantially the same structure has been developed twice over. Moreover, as I have pointed out $t$, the instrument is also found in another spider, Idiommata Blackwallii, Camb., which belongs to yet a third subfamily. So that apparently we have evidence that the organ has been independently acquired three times within the limits of a single group of spiders.

This conclusion at once raises the question as to the value of the character in uniting the genera that I have grouped together as Selenocosmiidæ. For it may well be asked what reasons there are for regarding it as a sign of affinity in the

- Ann. Mag. Nat. Hist. (6) xv. p. 178, pl. x. fg. $3 a$.

$\dagger$ Ann. Mag. Nat. Hist. (6) xvi. p. 225. 
case of the Selenocosmiidæ, when we do not claim it to be a sign of affinity between the Selenocosmiidæ and Idiommata and Trechona. 'To this it must be replied that Idiommata and Trechona are separated from each other and from the Selenocosmiidæ by certain other characters which do not admit of the genera presenting them being grouped in the same category. But the genera of Selenocosmiidæ are, apart from the presence of Wood-Mason's organ, much alike in all structural points; and this, coupled with the fact that they inhabit the same geographical area, lends great weight to the supposition that the mutual possession of Wood-Mason's organ may be regarded as an indication of relationship between them.

\section{PROCEEDINGS OF LEARNED SOCIETIES.}

\section{GEOLOGICAL SOCIETY.}

December 4, 1895.-Dr. Henry Woodward, F.R.S., President, in the Chair.

The following communication was read:-

'The Mollusca of the Chalk Rock. -Part I.' By Henry Woods, Esq., M.A., F.G.S.

In the introductory part of the paper the Author gives an account of the characters, distribution, and literature of the Chalk Rock. He points out that the Chalk Rock fauna may be recognized at the same level in Northern France, N.W. Germany, Saxony, Silesia, and Bohemia; and on account of the wide distribution and distinctive features of this fauna, he suggests that the Chalk Rock merits a palæontological rather than a lithological designation, and proposes for it the term 'zone of Heteroceras reussionum.'

The main part of the paper is devoted to the consideration of the cephalopoda, gasteropoda, and scaphopoda; and is based largely on the collection from Cuckhamsley (B.rks) made by the late Mr. Montagu Smith; but for the loan of many specimens the Author is indebted to Mr. R. M. Brydone, Mr. C. Griffith, Mr. W. Hill, Dr. J. Morison, and Mr. James Saunders. In addition to some genera, of which sufficiently good examples for exact determination have not yet been obtained, the following are represented :-Nautilus, Ptychoceras, Heteroceras, Baculites, Prionocyclus, Pachydiscus, Scaphites, Crioceras, Emarginula, Pleurotomaria, Trochus, Turbo, Crepidula, Natica, Cerithium, Aporrhais, Avellana, and Dentalium. Some new species are described, and the synonymy and distribution of the others treated in detail, figures and descriptious being given of the forms not previously well known. The account of the lamellibranchs and the general conclusions are reserved for Part II. 